\title{
Formulasi Sediaan Salep Ekstrak Daun Puring (Codiaeum variegatum L.) Dengan Basis Hidrokarbon Dan Larut Air
}

\author{
Formulation of Puring Leaf Extract Ointment (Codiaeum variegatum L.) With a Hydrocarbon \\ Base and Water Soluble Base
}

\author{
Repining Tiyas Sawiji(1) ${ }^{(1)}$ Ni Wayan Ari Sukmadiani(1) \\ Program Studi D3 Farmasi, Sekolah Tinggi Farmasi Mahaganesha Bali \\ Email: repiningtiyas@gmail.com
}

\begin{abstract}
ABSTRAK
Daun puring (Codiaeum variegatum L.) merupakan tanaman hias yang banyak digunakan sebagai bahan obat tradisional. Daun puring mengandung senyawa metabolit sekunder diantaranya terpenoida, flavonoida, saponin, alkaloida, dan tannin. Senyawa metabolit flavonoida diketahui memiliki aktivitas antibakteri. Salep merupakan sediaan semipadat yang bertujuan untuk penggunaan topikal, kualitas fisik sediaan salep tidak terlepas dari pemilihan basis yang cocok. Basis berfungsi sebagai pembawa dan pelindung dari sediaan salep. Tujuan dari penelitian ini adalah untuk memformulasikan sediaan salep ekstrak daun puring serta mengetahui pengaruh basis formula terhadap stabilitas fisiknya. Penelitian ini merupakan penelitian eksperimental laboratorium yang dilakukan dengan pengujian stabilitas fisik metode freeze thaw dan sifat fisik salep yang meliputi uji organoleptis, homogenitas, $\mathrm{pH}$, daya lekat, daya sebar, dan viskositas. Data dianalisis secara statistika dengan metode uji ANOVA dan Kruskal walis. Hasil penelitian menunjukkan bahwa ekstrak daun puring dapat diformulasikan menjadi sediaan salep dengan basis hidrokarbon dan basis larut air. Formulasi ekstrak daun puring terhadap basis hidrokarbon dan larut air berpengaruh terhadap stabilitas fisik seperti uji organoleptis, $\mathrm{pH}$, homogenitas, dan daya sebar namun tidak stabil pada uji viskositas dan daya lekat.

Kata kunci : Codiaeum variegatum L., Salep, Basis Hidrokarbon, Basis Larut Air, Stabilitas
\end{abstract} Fisik

\begin{abstract}
Puring leaf (Codiaeum variegatum L.) is an ornamental plant that is widely used as an ingredient in traditional medicine. Puring leaves contain secondary metabolites including terpenoids, flavonoids, saponins, alkaloids, and tannins. Flavonoid metabolite compounds are known to have antibacterial activity. Ointment is a semisolid preparation that is intended for topical use, the physical quality of the ointment preparation cannot be separated from the selection of a suitable base. The base serves as a carrier and protector of the ointment preparation. The purpose of this study was to formulate the preparation of puring leaf extract ointment and to determine the effect of the formula base on its physical stability. This research is an experimental laboratory research conducted by testing the physical stability of the freeze thaw method and the physical properties of the ointment which include organoleptic tests, homogeneity, $\mathrm{pH}$, adhesion, spreadability, and viscosity. The data were analyzed statistically by using ANOVA and Kruskal walis test methods. The results showed that puring leaf extract could be formulated into an ointment with a hydrocarbon base and a water soluble base. The formulation of puring leaf extract on a hydrocarbon base and water soluble affects the physical stability such as organoleptic tests, $\mathrm{pH}$,
\end{abstract}


homogeneity, and dispersibility but is not stable on viscosity and adhesion tests.

Keywords: Codiaeum variegatum L., Ointment, Hydrocarbon Base, Water Soluble Base, Physical stability

\section{PENDAHULUAN}

Infeksi merupakan jenis penyakit yang paling banyak diderita oleh penduduk di negara berkembang, termasuk Indonesia (Radji, 2011). Infeksi merupakan penyakit yang dapat ditularkan dari satu orang ke orang lain atau dari hewan ke manusia. Penyakit infeksi dapat disebabkan oleh mikroorganisme patogen.

Salah satu bahan alam yang memiliki kandungan antibakteri adalah daun puring (Codiaeum variegatum L.) yang dikenal dengan corak yang unik dan berwarna-warni. Sejak zaman dahulu masyarakat sudah mengetahui dan menggunakan tanaman ini sebagai obat herbal untuk menyembuhkan luka, jauh sebelum pelayanan kesehatan formal dan obat-obatan modern menyentuh masyarakat. Berdasarkan hasil uji fitokimia yang dilakukan oleh Bijekar and Gayatri (2015), menunjukkan bahwa daun puring mengandung senyawa sekunder seperti flavonoida, terpenoida, tannin, saponin, dan alkaloida. Menurut penelitian yang dilakukan oleh Hermanus (2001), menyatakan bahwa ekstrak daun puring dengan konsentrasi 1600 $\mu \mathrm{g} / \mathrm{ml}$ dapat menghambat bakteri Staphylococcus aureus dan Eschericia coli dengan zona hambatan masing-masing adalah 7,0 $\mathrm{mm}$ dan 7,5 $\mathrm{mm}$.

Sediaan salep merupakan salah satu bentuk sediaan farmasi yang digunakan pada pengobatan yang dimaksudkan untuk efek topikal. Salep digunakan untuk mengobati penyakit kulit yang akut atau kronis sehingga diharapkan adanya berpenetrasi kedalam lapisan kulit agar dapat memberikan efek yang diinginkan (Voigt, 1984). Selain itu salep lebih banyak disukai karena lebih mudah, praktis, menimbulkan rasa dingin, mempermudah perbaikan kulit, menjadikan kulit lembab atau menghasilkan efek emollient serta mengantarkan obat pada kulit untuk efek khusus topikal atau sistemik. Formulasi pada sediaan salep akan mempengaruhi jumlah dan kecepatan zat aktif yang dapat diabsorpsi. Pelepasan obat dari sediaan salep juga dipengaruhi oleh sifat fisik dari sediaan salep yang akan dibuat. Sifat fisik disini tergantung pula dari jenis basis dan formulasinya (Fatimah, 2017).

Sediaan salep ekstrak daun puring menggunakan dua tipe basis salep yaitu basis salep hidrokarbon dan basis salep larut air. Tujuan formulasi dari ekstrak daun puring adalah untuk pengobatan infeksi pada permukaan kulit. Terdapat beberapa macam basis salep seperti basis salep hidrokarbon dapat dipakai terutama untuk efek emollient. Basis salep tersebut bertahan pada kulit untuk waktu yang lama dan tidak memungkinkan menguap ke udara dan sukar dicuci (Ansel, 1989). Basis larut air seperti contoh PEG tidak mengiritasi, memiliki daya lekat dan distribusi yang baik pada kulit, tidak menghambat pertukaran gas dan produksi keringat, sehingga efektifitas lebih lama dan juga dapat digunakan pada bagian tubuh yang berambut (Voigt, 1995). Perbedaan tipe basis salep dimaksudkan untuk mengetahui tipe basis salep yang cocok untuk salep ekstrak daun puring serta memiliki stabilitas fisik yang baik.

Berdasarkan uraian diatas, maka perlu dilakukan penelitian untuk memformulasikan sediaan salep ekstrak daun puring (Codieum variegatum L.) dan mengetahui pengaruh tipe 
basis hidrokarbon dan basis larut air terhadap stabilitas fisiknya.

\section{METODE PENELITIAN}

\section{Alat dan Bahan}

Bahan yang digunakan dalam penelitian ini adalah ekstrak daun puring (Codiaeum variegatum $\mathrm{L}$.), vaselin album (Bratachem), cera alba, PEG 400, PEG 4000, stearil alkohol (Bratachem), metil paraben (Bratachem), propilparaben (Bratachem), BHT (butil hidroksi toluene).

Alat yang digunakan dalam penelitian ini adalah mortir dan stamper, Waterbath (Memmert), timbangan digital (ACIS AF- 300i; Ohaus), batang pengaduk, sendok tanduk, sendok porselen, beaker glass (Pyrex), cawan porselen, $\mathrm{pH}$ strip, uji daya sebar, uji daya lekat, viskometer (Rion VT- 6), sudip, wadah salep, kulkas, blender.

\section{Metode Penelitian}

\section{a. Determinasi tanaman}

Daun Puring (Codiaeum variegatum L.) diidentifikasi dengan tujuan untuk melihat taksonomi tanaman yang digunakan dalam penelitian ini. Determinasi dilakukan di Lembaga Ilmu Pengetahuan Indonesia (LIPI) Eka Karya Bedugul-Bali.

\section{b. Pembuatan Simplisia}

Daun puring segar dipisahkan dari batang dan rantingnya, kemudian dirajang kecil-kecil lalu dilakukan sortasi basah dengan tujuan menghilangkan kotoran yang menempel pada daun puring. Kemudian dilakukan pengeringan dengan diangin-anginkan yang bertujuan untuk mengurangi kadar air pada simplisia, untuk mencegah jamur dan menjaga simplisia tetap baik dalam penyimpanan. Setelah itu dilakukan sortasi kering dengan tujuan memisahkan kotoran-kotoran yang memungkinkan bercampur dengan simplisia, kemudian simplisia kering diblender hingga diperoleh serbuk simplisia.

\section{c. Pembuatan Ekstrak}

Pembuatan ekstrak kental daun puring menggunakan metode maserasi dengan pelarut etanol 96\%. Proses maserasi dilakukan selama $3 \times 24$ jam dengan sesekali dilakukan pengadukan. Kemudian disaring hingga diperoleh residu dan filtrat. Residu yang diperoleh dilakukan remaserasi dengan tujuan untuk mendapatkan ekstrak yang lebih banyak. Filtrat yang dihasilkan kemudian dievaporasi hingga diperoleh ekstrak kental. Ekstrak kental yang diperoleh dilakukan penimbangan bobotnya dengan simplisia awal untuk dinyatakan rendemennya.

\section{d. Rancangan Formulasi}

Formulasi sediaan salep ekstrak daun puring menggunakan dasar salep hidrokarbon (formula A) dan dasar salep larut air (formula B). formulasi salep ekstrak daun puring dapat dilihat pada Tabel 1.

Tabel 1. Formulasi Salep Ekstrak Daun Puring

\begin{tabular}{lcc}
\hline \multirow{2}{*}{\multicolumn{1}{c}{ Bahan }} & \multicolumn{2}{c}{ Konsentrasi } \\
\cline { 2 - 3 } & $\mathrm{A}$ & $\mathrm{B}$ \\
\hline Ekstrak Daun Puring & $0,08 \mathrm{~g}$ & $0,08 \mathrm{~g}$ \\
BHT & $0,02 \mathrm{~g}$ & $0,02 \mathrm{~g}$ \\
Vaselin album & $46,40 \mathrm{~g}$ & - \\
Cera alba & $3 \mathrm{~g}$ & - \\
PEG 400 & - & $26,64 \mathrm{~g}$ \\
PEG 4000 & - & $17,76 \mathrm{~g}$ \\
Stearil alkohol & - & $5 \mathrm{~g}$ \\
Metil paraben & $0,2 \mathrm{~g}$ & $0,2 \mathrm{~g}$ \\
Propil paraben & $0,3 \mathrm{~g}$ & $0,3 \mathrm{~g}$ \\
\hline
\end{tabular}

\section{e. Pembuatan Salep}

Sediaan salep ekstrak daun puring dengan basis hidrokarbon menggunakan vaselin album, cera alba,dan metil paraben sedangkan untuk basis larut air menggunakan PEG 400, PEG 4000, 
stearil alkohol, dan metil paraben. Semua bahan dilebur diatas penangas air dengan menggunakan cawan porselen hingga meleleh dan sesekali diaduk hingga homogen dan membentuk massa salep. Setelah massa salep terbentuk, selanjutnya dipindahkan ke mortir kemudian ditambahkan ekstrak daun puring sedikit demi sedikit digerus hingga homogen, kemudian tambahkan butil hidroksi tuolene dan propil paraben dicampur hingga homogen. Kemudian dimasukkan kedalam pot salep.

\section{f. Evaluasi Sediaan Uji organoleptik}

Pengujian organoleptik dilakukan dengan mengamati sediaan salep dari bentuk, bau dan warna sediaan. Spesifikasi salep yang harus dipenuhi adalah memilih bentuk setengah padat, warna harus sesuai dengan spesifikasi pada saat pembuatan awal salep dan baunya tidak tengik (Sari, Hudha and Prihanta, 2016).

\section{Uji homogenitas}

Pengujian homogenitas sediaan salep dilakukan dengan cara mengoleskan salep pada kaca objek glass. Sediaan yang homogen ditandai dengan tidak terdapatnya gumpalan pada saat dioleskan, Salep yang di uji diambil di tiga tempat antara lain pada bagian atas, tengah dan bawah dari wadah salep (Sari, Hudha and Prihanta, 2016)

\section{Uji daya sebar}

Ditimbang sediaan sebanyak $0,5 \mathrm{~g}$ dan diletakan ditengah kaca objek glass. Letakkan kaca penutup diatas salep dan biarkan 1 menit, catat diameter sebar nya. Kemudian tambahkan beban $50 \mathrm{~g}$ dan biarkan 1 menit, catat diameter sebarnya. Ulangi hingga beban $150 \mathrm{~g}$. Kemudian diukur diameter salep yang menyebar (dengan mengambil panjang rata-rata diameter dari beberapa sisi). Diameter daya sebar sediaan salep yang baik antara 5-7 cm (Sari, Hudha and Prihanta, 2016).

\section{Uji pH salep}

Pengujian $\mathrm{pH}$ bertujuan untuk mengetahui kesesuaian $\mathrm{pH}$ sediaan salep yang dibuat dengan $\mathrm{pH}$ kulit. Uji pH dilakukan pada kedua formula dengan menguji sejumlah $0,5 \mathrm{~g}$ sampel salep diencerkan dengan akuades sebanyak $50 \mathrm{ml}$, kemudian dicelupkan $\mathrm{pH}$ strip kedalam sampel, $\mathrm{pH}$ yang tertera dicatat. $\mathrm{pH}$ sediaan topikal umumnya dikatakan baik jik $\mathrm{pH}$ sediaan berada pada rentang pH kulit yakni 4,5-6,5 (Naibaho, Yamlean and Wiyono, 2013).

\section{Uji daya lekat}

Uji ini dilakukan untuk mengetahui lamanya salep melekat pada kulit. Ditimbang sediaan salep sebanyak $0,5 \mathrm{~g}$, diatasnya diletakkan objek glass yang lain kemudian diberi beban $500 \mathrm{~g}$ selama 5 menit. Selanjutnya objek glass dipasang pada alat uji daya lekat, kemudian melepaskan beban seberat $100 \mathrm{~g}$ dan dicatat waktunya hingga kedua obyek gelas tersebut lepas. Daya lekat pada sediaan topikal direkomendasikan lebih dari 4 detik (Widyantoro and Sugihartini, 2015).

\section{Viskositas}

Uji ini dilakukan untuk mengetahui kekentalan sedian salep dengan cara menggunakan alat viskometer digital, uji viskositas dilakukan dengan masukkan salep kedalam wadah berbentuk cup kemudian di pasang spindle kemudian amati hasil viskositas pada layar viscometer (Widyantoro and Sugihartini, 2015).

\section{Uji stabilitas}

Uji stabilitas menggunakan metode freeze thaw. Metode ini dilakukan karena termasuk stabilitas yang dipercepat dimana hanya memerlukan 
waktu selama 2 minggu, sehingga dilakukan sebanyak 6 siklus selama 12 hari dimana 1 siklus dilakukan selama 2 hari yaitu 1 x 24 jam pada suhu kamar $27^{\circ} \mathrm{C} \pm 2^{\circ} \mathrm{C}$ dan 1 x 24 jam pada suhu $4^{\circ} \mathrm{C} \pm 2{ }^{\circ} \mathrm{C}$ (Agustin, Oktadefitri and Lucida, 2013)

\section{g. Analisis Data}

Data yang diperoleh dari penelitian ini, dianalisis dengan menggunakan analisis data meliputi uji normalitas, uji homogenitas, ANOVA dan uji Kruskal Walis yang dibantu dengan Program Statistical Package for the Social Sciences (SPSS) versi 16. Yang dilakukan pada pengujian daya sebar, daya lekat dan viskositas. Data disajikan dalam bentuk tabel, atau gambar sesuai dengan hasil yang didapatkan.

\section{HASIL DAN PEMBAHASAN \\ Hasil}

\section{Hasil Pembuatan Ekstrak Daun Puring}

Determinasi tanaman yang dilakukan di Lembaga Ilmu Pengetahuan Indonesia (LIPI), UPT Balai Konservasi Tumbuhan Kebun Raya " Eka Karya " Bali dengan hasil yaitu tanaman daun puring merupakan spesies Codiaeum variegatum (L.) Rumph. Ex A.Juss. yang berasal dari suku (familia) Euphorbiaceae. Hasil pembuatan serbuk daun puring yang sudah dilakukan pengolahan didapatkan serbuk daun puring sebanyak $900 \mathrm{~g}$ dengan rendemen simplisia sebanyak 25,71\%. Kemudian simplisia kering dimaserasi selama 3 hari dengan pelarut etanol 96\% hingga diperoleh ekstrak kental sebanyak 49,51 g dengan nilai rendemen 6,61\%.

\section{Hasil Pengujian}

\section{Uji organoleptis dan homogenitas}

Sediaan salep yang dihasilkan diamati penampilan fisiknya secara organoleptis dan homogenitas serta diukur daya sebar, daya lekat, dan $\mathrm{pH}$. Pengamatan uji organoleptis bertujuan

untuk mengamati penampilan luar dari sediaan. Sedangkan uji homogenitas bertujuan untuk melihat apakah sediaan salep yang dibuat homogen atau terdistribusi secara merata antara zat aktif dengan basis salep. Hasil sediaan salep ekstrak daun puring dapat dilihat pada Gambar 1.

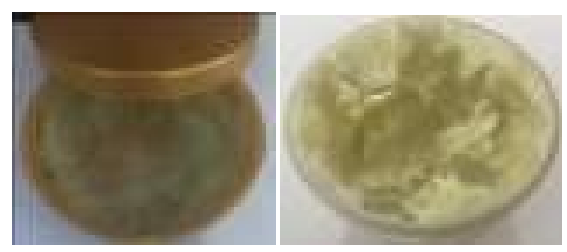

(A)

(B)

Gambar 1. Penampilan fisik salep ekstrak daun puring

Keterangan gambar :

Formula A : Basis salep hidrokarbon

Formula B : Basis salep larut air

Sediaan salep dibuat dengan 2 variasi basis yaitu basis hidrokarbon dan basis larut air, hasil uji organoleptis menunjukkan salep dengan basis hidrokarbon memiliki bentuk setengah padat atau lebih lembek dibandingkan salep dengan basis larut air yang memiliki bentuk setengah padat yang lebih padat. Salep ekstrak daun puring memiliki warna yang berbeda tergantung jens basis yang digunakan yaitu salep basis hidrokarbon menunjukkan warna hijau, sedangkan basis larut air menunjuka warna hijau muda. Hasil pemeriksaan bau yang diamati sediaan salep menunjukan basis hidrokarbon dari siklus ke pertama sampai keenam tidak mengalami perubahan warna, bau, dan bentuk sehingga memenuhi persyaratan sediaan salep sedangkan pada basis larut air mengalami perubahan bau pada siklus ketiga sampai keenam. Pengujian homogenitas dilakukan untuk mengetahui homogenitas dari formula sediaan salep yang 
diteliti, dari kedua formula menunjukkan sediaan salep memberikan susunan yang homogen dibuktikan dengan tidak adanya butiran kasar dan mengumpal pada sediaan. Konsistensi bentuk fisik salep tidak mengalami perubahan, yakni tidak ada pemisahan ataupun ketidakseragaman dalam bentuknya. Dengan demikian, semua sediaan salep mempunyai homogenitas yang baik dan memenuhi persyaratan Farmakope Indonesia edisi III, yaitu jika salep dioleskan pada sekeping kaca atau bahan transparan lain yang cocok harus menunjukkan susunan yang homogen yang dapat dilihat dengan tidak adanya partikel yang bergerombol dan menyebar secara merata. Sediaan salep yang homogen mengindikasikan bahwa bahan -bahan yang digunakan dalam pembuatan salep tercampur sempurna. Suatu sediaan salep harus homogen dan terdistribusi merata agar tidak menyebabkan iritasi ketika dioleskan pada permukaan kulit. Hal ini berarti perbedaan tipe basis salep yang digunakan dalam pembuatan salep ekstrak daun puring berpengaruh terhadap homogenitas salep. Hasil uji organoleptik dn homogenitas dapat dilihat pada Tabel 2.

Tabel 2. Hasil uji organoleptik dan homogenitas salep ekstrak daun puring

\begin{tabular}{|c|c|c|c|c|c|}
\hline & & \multicolumn{3}{|c|}{ Uji organoleptis } & \multirow{2}{*}{ Homogenitas } \\
\hline \multicolumn{2}{|c|}{ Siklus * } & Bentuk & Bau & Warna & \\
\hline \multirow{7}{*}{ Formula A } & 0 & Setengah padat & Tidak berbau & Hijau & Homogen \\
\hline & 1 & Setengah padat & Tidak berbau & Hijau & Homogen \\
\hline & 2 & Setengah padat & Tidak berbau & Hijau & Homogen \\
\hline & 3 & Setengah padat & Tidak berbau & Hijau & Homogen \\
\hline & 4 & Setengah padat & Tidak berbau & Hijau & Homogen \\
\hline & 5 & Setengah padat & Tidak berbau & Hijau & Homogen \\
\hline & 6 & Setengah padat & Tidak berbau & Hijau & Homogen \\
\hline \multirow{7}{*}{ Formula B } & 0 & Setengah padat & Tidak berbau & Hijau muda & Homogen \\
\hline & 1 & Setengah padat & Tidak berbau & Hijau muda & Homogen \\
\hline & 2 & Setengah padat & Tidak berbau & Hijau muda & Homogen \\
\hline & 3 & Setengah padat & Tengik & Hijau muda & Homogen \\
\hline & 4 & Setengah padat & Tengik & Hijau muda & Homogen \\
\hline & 5 & Setengah padat & Tengik & Hijau muda & Homogen \\
\hline & 6 & Setengah padat & Tengik & Hijau muda & Homogen \\
\hline
\end{tabular}




\section{Karakteristik Sediaan Salep Uji pH}

Uji $\mathrm{pH}$ dilakukan sebagai dasar untuk mengevalusi keamanan sediaan salep saat diaplikasikan dikulit. $\mathrm{pH}$ diukur menggunakan $\mathrm{pH}$ strip yang dicelupkan kedalam sediaan salep, kemudian dibandingkan warna $\mathrm{pH}$ dengan skala warna pada indikator. $\mathrm{pH}$ sediaan salep sebaiknya mendekati $\mathrm{pH}$ normal kulit yaitu antara 4,5-6,5 atau sesuai dengan nilai $\mathrm{pH}$ kulit manusia. Agar tidak merubah fisiologis kulit, karena $\mathrm{pH}$ yang terlalu asam dapat menyebabkan iritasi pada kulit sedangkan jika $\mathrm{pH}$ terlalu basa dapat menyebabkan kulit bersisik (Sandi and Musfirah, 2018). Hasil pengamatan $\mathrm{pH}$ yang diperoleh dari siklus pertama sampai ke enam sediaan salep ekstrak daun puring pada kedua basis salep berada di pH 6 dan telah memenuhi syarat nilai $\mathrm{pH}$ yang aman untuk kulit. Sehingga dapat disimpulkan bahwa perbedaan tipe basis salep dalam pembuatan salep ekstrak daun puring tidak berpengaruh terhadap $\mathrm{pH}$ salep. Namun kejadian ini mungkin diakibatkan oleh penggunaan $\mathrm{pH}$ strip dalam pengujian $\mathrm{pH}$ yang memiliki sensitivitas rendah (hanya mampu mendeteksi perbedaan $\mathrm{pH}$ diatas 1 unit). Oleh karena itu, sebaiknya mengunakan $\mathrm{pH}$ meter untuk mendapatkan hasil yang baik.

\section{Uji Daya Sebar}

Daya sebar salep dapat didefinisikan sebagai kemampuan menyebarnya salep pada permukaan kulit yang akan diobati. Suatu sediaan salep diharapkan mampu menyebar dengan mudah ditempat pemberian, tanpa menggunakan tekanan yang berarti. Semakin mudah dioleskan maka luas permukaan kontak obat dengan kulit semakin besar, sehingga absorbsi obat ditempat pemberian semakin optimal (Nareswari and Kuncoro, 2017). Sediaan salep dikatakan baik apabila daya menyebarnya besar (diameter), diameter penyebaran salep yang baik antara $5-7 \mathrm{~cm}$ (Sari, Hudha and Prihanta, 2016). Dari ke 2 formulasi tipe basis hidrokarbon dan larut air didapatkan luas permukaan daya sebar dari siklus ke 0 sampai siklus 6 yaitu formulasi A yaitu rata-rata $1-2 \mathrm{~cm}$ dan formula $B$ yaitu rata-rata $0-1 \mathrm{~cm}$ dari kedua formula tidak memenuhi persyaratan diameter sebar. Dilihat dari nilai rata-rata, basis hidrokarbon menunjukkan daya sebar yang besar sedangkan pada basis larut air menunjukkan daya sebar yang kecil. Hal ini dipengaruhi karena basis hidrokarbon memiliki konsistensi yang lembek atau lunak, sehingga memudahkan sediaan untuk menyebar, namun untuk basis larut air memiliki konsistensi yang padat dan keras sehingga daya menyebarnya kecil. Tipe basis salep dapat mempengaruhi daya sebar, karena tiap basis salep memiliki konsistensi yang berbeda. Hal ini sama dengan penelitian yang dilakukan Puspitasari (2012) yang menunjukkan bahwa basis salep berpengaruh terhadap daya sebar. Hasil uji daya sebar dapat dilihat pada Tabel 3.

Tabel 3. Hasil uji daya sebar daun puring (cm)

\begin{tabular}{|c|c|c|}
\hline Formula & Siklus & $\mathrm{x} \pm \mathrm{SD}$ \\
\hline \multirow{4}{*}{ A } & 0 & $7,75 \pm 1,76$ \\
\cline { 2 - 3 } & 1 & $9,50 \pm 0,70$ \\
\cline { 2 - 3 } & 2 & $11,3 \pm 3,21$ \\
\cline { 2 - 3 } & 3 & $12,5 \pm 2,50$ \\
\cline { 2 - 3 } & 4 & $12,5 \pm 5,89$ \\
\cline { 2 - 3 } & 5 & $13,2 \pm 1,06$ \\
\hline \multirow{4}{*}{ B } & 6 & $14,1 \pm 1,44$ \\
\cline { 2 - 3 } & 0 & $4,00 \pm 1,14$ \\
\cline { 2 - 3 } & 1 & $3,16 \pm 1,75$ \\
\cline { 2 - 3 } & 2 & $2,25 \pm 1,06$ \\
\cline { 2 - 3 } & 3 & $2,25 \pm 1,06$ \\
\cline { 2 - 3 } & 4 & $3,50 \pm 1,80$ \\
\cline { 2 - 3 } & 5 & $4,00 \pm 1,41$ \\
\hline
\end{tabular}

Uji normalitas daya sebar dari kedua formula bertujuan untuk mengetahui apakah data yang didapat terdistribusi normal atau tidak. Uji normalitas dilakukan dengan menggunakan Shapiro-Wilk, karena data yang digunakan kurang dari 50 (Dahlan, 2014). Data dikatakan terdistribusi normal apabila memenuhi ketentuan nilai signifikansi $\mathrm{P}>0,05$, Hasil yang diperoleh dari data daya sebar menunjukkan bahwa data daya sebar kedua formulasi tidak terdistribusi normal 
karena nilai siq. $0,00<0,05$. Uji Homogenitas dilakukan pada kedua formula untuk mengetahui apakah data yang diperoleh homogen atau tidak. Hasil yang diperoleh dari data daya sebar menunjukkan nilai untuk $\mathrm{F}(\mathrm{A})$ adalah 0,959 dan $\mathrm{F}(\mathrm{B})$ adalah 0,316 dimana $\mathrm{p}>0,05$, oleh karena $\mathrm{p}>0,05$ maka dapat disimpulkan bahwa data terdistribusi homogen (Oktaviani, Purwijantiningsih and Pranat, 2014). Dari data diatas disimpulkan bahwa kedua formula tidak terdistribusi normal tetapi homogen, sehingga analisis dilanjutkan dengan uji non-parametrik yaitu uji Kruskal Walis.

Tabel 4. Hasil Uji Statistika Kruskal Walis Daya Sebar

\begin{tabular}{cc}
\hline Formula & Asymp.Sig \\
\hline A & $0,230^{*}$ \\
B & $0,464^{*}$
\end{tabular}

$* \mathrm{p}<0,05$

Uji stabilitas fisik daya sebar dilakukan dengan uji non parametik yaitu uji Kruskal Walis yang digunakan untuk mengetahui ada atau tidak pergaruh daya sebar dari kedua formula dengan asumsi data tidak terdistribusi normal. Dilihat dari hasil statistika diperoleh nilai Asymp. Signifikasi pada $F(A)$ adalah 0,230 dan $F(B)$ adalah 0,464 yang artinya terdapat perbedaan daya sebar. Sedangkan jika dilihat dari hasil pengujian daya sebar siklus 0 sampai siklus 6 terjadi perubahan rata-rata pada kedua formula. Sehingga dapat disimpulkan bahwa kedua formula stabil.

\section{Uji Daya Lekat}

Pengujian ini dilakukan untuk mengetahui seberapa lama waktu perekatan sediaan salep pada permukaan kulit. Semakin kental konsistensi sediaan maka waktu yang dibutuhkan untuk memisahkan kedua obyek glass menjadi semakin lama (Widyantoro and Sugihartini, 2015). sehingga apabila konsistensi salep semakin kental maka kontak obat pada permukaan kulit juga semakin lama. Syarat untuk daya lekat pada sediaan topikal adalah tidak kurang dari 4 detik (Ulaen, Banne and Suatan, 2012). Hasil yang didapatkan dalam penelitian ini dapat dilihat pada lampiran yaitu formula A memiliki daya lekat antara 1-2 detik dan formula B memiliki daya lekat antara 11-40 detik. Hasil pengujian daya lekat dapat dilihat pada Tabel 5.

Tabel 5. Hasil uji daya lekat daun puring (detik)

\begin{tabular}{|c|c|c|}
\hline Formula & Siklus & $\mathrm{x} \pm \mathrm{SD}$ \\
\hline \multirow{4}{*}{ A } & 0 & $1,47 \pm 0,21$ \\
\cline { 2 - 3 } & 1 & $1,13 \pm 0,2$ \\
\cline { 2 - 3 } & 2 & $2,50 \pm 0,73$ \\
\cline { 2 - 3 } & 3 & $2,29 \pm 0,22$ \\
\cline { 2 - 3 } & 4 & $1,06 \pm 0,23$ \\
\cline { 2 - 3 } & 5 & $1,37 \pm 0,38$ \\
\cline { 2 - 3 } & 6 & $2,42 \pm 0,29$ \\
\hline \multirow{4}{*}{ B } & 0 & $3,1 \pm 2,11$ \\
\cline { 2 - 3 } & 1 & $11,3 \pm 1,00$ \\
\cline { 2 - 3 } & 2 & $24,2 \pm 10,2$ \\
\cline { 2 - 3 } & 3 & $2,25 \pm 1,06$ \\
\cline { 2 - 3 } & 4 & $28,2 \pm 13,0$ \\
\cline { 2 - 3 } & 5 & $40,3 \pm 7,97$ \\
\cline { 2 - 3 } & 6 & $38,6 \pm 16,2$ \\
\hline
\end{tabular}

Data yang diperoleh dari siklus ke 0 sampai siklus ke 6 memiliki nilai SD yang rendah dari nilai rata-rata, sehingga daya lekat mudah menyebar. Berdasarkan uji daya lekat untuk basis hidrokarbon mendapatkan hasil yang kecil sedangkan pada basis larut air menunjukkan hasil yang sebaliknya. Semakin lama daya lekat maka viskositasnya semakin tinggi. Basis salep mempengaruhi daya lekat karena tiap basis memiliki viskositas yang berbeda. Penelitian yang pernah dilakukan Puspitasari (2012) menunjukkan bahwa basis salep mempengaruhi daya lekat karena memiliki konsistensi yang berbeda sehingga waktu daya lekat berbeda.

Uji normalitas daya lekat dari kedua formula yang bertujuan untuk mengetahui apakah data yang didapat terdistribusi normal atau tidak. Uji normalitas dilakukan dengan menggunakan Shapiro-Wilk, karena data yang digunakan kurang 
dari 50 (Dahlan, 2014). Data dikatakan terdistribusi normal apabila memenuhi ketentuan nilai signifikansi $\mathrm{P}>0,05$, Hasil yang diperoleh menunjukkan bahwa besarnya nilai signifikasi untuk $\mathrm{F}(\mathrm{A})$ adalah 0.000 , dan $\mathrm{F}(\mathrm{B})$ adalah 0,363. Nilai signifikasi untuk $F(B)$ diatas atau lebih besar dari 0,05 artinya daya lekat terdistribusi normal namun untuk $\mathrm{F}(\mathrm{A})$ dibawah atau lebih kecil dari 0,05 artinya daya lekat tidak terdistibusi normal. Pemilihan uji Saphiro Wilk dikarenakan metode uji normalitas ini memiliki kosistensi hasil keputusan paling baik (Oktaviani, Purwijantiningsih and Pranat, 2014). Uji Homogenitas untuk mengetahui apakah data homogen atau tidak, dari hasil yang diperoleh dari $\mathrm{F}(\mathrm{A})$ adalah 0,04 dan $\mathrm{F}(\mathrm{B})$ adalah 0,06 . Nilai signifikasi untuk $F(B)$ diatas atau lebih besar dari 0,05 artinya daya lekat terdistribusi homogen namun untuk $\mathrm{F}(\mathrm{A})$ dibawah atau lebih kecil dari 0,05 artinya daya lekat tidak terdistribusi homogen. Kemudian F(B) dilanjutkan dengan pengujian parametrik yaitu uji ANOVA sedangkan F(A) dilakukan uji non parametrik Kruskal Walis.

Uji stabilitas dilakukan dengan uji Kruskal Walis pada $\mathrm{F}(\mathrm{A})$ dan $\mathrm{F}(\mathrm{B})$ dengan uji ANOVA untuk mengetahui ada atau tidaknya pengaruh daya lekat selama siklus ke 0 sampai siklus ke 6 . dari hasil statistika diperoleh nilai Asymp. Signifikasi pada F(A) adalah 0,013 dan F(B) adalah 0,010 yang artinya terdapat perbedaan daya lekat. Sedangkan jika dilihat dari hasil pengujian daya lekat siklus 0 sampai siklus 6 terjadi perubahan rata-rata pada kedua formula. Sehingga dapat disimpulkan bahwa kedua formula berpengaruh terhadap daya lekat dan tidak stabil.

Tabel 6. Hasil Uji Statistika Daya Lekat

\begin{tabular}{ccc}
\hline Formula & Jenis Uji & Asymp.Sig \\
\hline A & Kruskal Walis & $0,013^{*}$ \\
B & ANOVA & $0,010^{*}$ \\
\hline
\end{tabular}

$* \mathrm{p}<0,05$

\section{Viskositas}

Pengujian viskositas dilakukan untuk mengetahui kekentalan suatu sediaan semisolid dengan menggunakan alat viskosimeter. Viskositas adalah suatu pernyataan tahanan dari cairan untuk mengalir, semakin tinggi viskositas maka akan semakin besar tahanannya. Semakin besar viskositas maka akan semakin besar tahanan suatu senyawa obat keluar dari basisnya, sehingga pelepasan obat dari basisnya semakin lambat tetapi sebaliknya bila semakin rendah viskositas maka akan mudah keluar dari basisnya menuju tempat yang akan diobati sehingga pelepasan obat menjadi lebih cepat. Rentang viskositas yang memenuhi persyaratan adalah 20-500 dPas.

Hasil yang diperoleh viskositas $F(A)$ menunjukkan hasil yang lebih kecil sedangkan pada $\mathrm{F}(\mathrm{B})$ menunjukkan hasil yang lebih besar. Hal ini menunjukkan terjadinya penurunan viskositas pada kedua formula. Penurunan viskositas selama penyimpanan diduga terjadi karena adanya kenaikan ukuran partikel yang menyebabkan luas permukaannya semakin kecil yang kemudian mengakibatkan viskositas menurun (Natalie, Mulyani and Admadi, 2017). Semakin besar viskositas maka daya menyebarnya menjadi semakin kecil. Salep yang mempunyai viskositas yang rendah akan memudahkan saat pemakaian serta pengambilan dari wadah menjadi lebih mudah karena konsistensinya lunak. Viskositas sediaan salep berhubungan erat dengan daya lekat, karena semakin tinggi viskositas maka kemampuan salep untuk melekat juga semakin lama (Marchaban and Sulaiman, 2014)

Uji normalitas dari kedua formula bertujuan untuk mengetahui apakah data yang didapat terdistribusi normal atau tidak. Uji normalitas dilakukan dengan menggunakan Shapiro-Wilk, karena data yang digunakan kurang dari 50 (Dahlan, 2014). Data dikatakan terdistribusi normal apabila memenuhi ketentuan nilai signifikansi $\mathrm{P}>0,05$, Hasil yang diperoleh menunjukkan bahwa besarnya nilai signifikasi adalah 1.00. Nilai signifikasi kedua formula diatas atau lebih besar dari 0,05 artinya data viskositas kedua formula terdistibusi normal. Pemilihan uji 
Saphiro Wilk dikarenakan metode uji normalitas ini memiliki kosistensi hasil keputusan paling baik (Oktaviani, Purwijantiningsih and Pranat, 2014).

Uji homogenitas pada kedua formula untuk mengetahui apakah daya yang diperoleh homogen atau tidak. Hasil yang diperoleh menunjukkan bahwa besarnya nilai signifikasi adalah 1.00. Nilai signifkasi kedua formula diatas lebih dari 0,05 artinya data terdistribusi homogen. Terpenuhinya normalitas dan homogenitas data menandakan analisa data dapat dilanjutkan dengan uji parametrik Anova. Uji stabilitas dari kedua formula dilakukan uji ANOVA untuk mengetahui ada atau tidaknya pengaruh viskositas selama siklus 0 sampai 6 . hasil yang didapatkan dapat dilihat pada Tabel 7.

Tabel 7. Hasil Uji Stabilitas Fisik Viskositas

\begin{tabular}{cc}
\hline Formula & Asymp.Sig \\
\hline A & $0,008^{*}$ \\
B & $0,080^{*}$ \\
\hline
\end{tabular}

$* \mathrm{p}<0,05$

Dari hasil Tabel diatas dapat disimpulkan bahwa pada $F(B)$ tidak terdapat perbedaan viskositas, sehingga dapat disimpulkan basis hidrokarbon berpengaruh terhadap viskositas, sedangkan pada basis larut air tidak berpengaruh serta pada kedua formulasi tidak stabil terhadap viskositas selama siklus 0 sampai 6 .

\section{SIMPULAN}

Berdasarkan hasil penelitian dapat disimpulkan bahwa ekstrak daun puring dapat diformulasikan menjadi sediaan salep dengan basis salep hidrokarbon dan basis larut air. Formulasi ekstrak daun puring dengan basis salep hidrokarbon dan larut air berpengaruh terhadap stabilitas fisik seperti organoleptis, $\mathrm{pH}$, homogenitas, dan daya sebar namun tidak stabil pada uji viskositas dan daya lekat.

\section{DAFTAR PUSTAKA}

Agustin, R., Oktadefitri, Y. and Lucida, H. (2013) 'Formulasi Krim Tabir Surya Dari Kombinasi Etil p-Metoksisinamat Denga Katekin', Prosiding Seminar Nasional Perkembangan Terkini Sains Farmasi dan Klinik III, pp. 184-198.

Ansel, H. C. (1989) Pengantar Bentuk Sediaan Farmasi, Edisi 4. Jakarta: Press UI.

Bijekar, S. R. and Gayatri, M. C. (2015) 'Phytochemical profile of Codiaeum variegatum (L.) Bl', International Journal of Pharmacology and Pharmaceutical Sciences, 2(3), pp. 22-31. Available at: http://ijppsjournal.org.

Dahlan, M. S. (2014) Statistik untuk Kedokteran dan Kesehatan. 6th edn. Jakarta: Salmba Medika.

Fatimah, Y. (2017) 'Pengaruh Basis Salep Terhadap Sifat Fisik Sediaan Salep Ekstrak Etanolik Bonggol Pisang Ambon (Musa paradisiaca var. sapientum L.) Sebagai Penyembuh Luka Terbuka Pada Tikus', pp. 7-12.

Hermanus, Y. O. (2001) 'Uji Daya Antibakteri Ekstrak Etanol Dan Rebusan Daun Puring (Codiaeum variegatum BL.) Terhadap Staphylococcus aureus dan Escherichia coli Secara Invitro'.

Marchaban and Sulaiman, T. N. . (2014) Petunjuk Praktikum Formulasi dan Teknologi Sediaan Cair dan Semipadat. Yogyakarta: Fakultas Farmasi UGM.

Naibaho, O. H., Yamlean, P. V. Y. and Wiyono, W. (2013) 'Pengaruh Basis Salep Terhadap Formulasi Sediaan Salep Ekstrak Daun Kemangi (Ocimum sanctum L.) Pada Kulit Punggung Kelinci yang Dibuat Infeksi Staphylococcus aureus', Jurnal Ilmiah Farmasi-UNSRAT, 2(2), pp. 27-34.

Nareswari, N. and Kuncoro, A. (2017) 'Preparation of essential oil ointment of lime leaves (Citrus amblycarpa) and stability test on base type used', Biofarmasi Journal of Natural Product Biochemistry, 14(2), pp. 63-68. doi: 10.13057/biofar/f140204. 
Natalie, A., Mulyani, S. and Admadi, B. H. (2017) 'Hubungan Lama Simpan Dengan Karakteristik Mutu pada Beberapa Formulasi Krim Ekstrak Kunyit (Curcuma domestica Val.)', Jurusan Teknologi Industri Pertanian, Mahasiswa Teknologi Pertanian Unud, Fakultas Jurusan Teknologi Industri Pertanian, Dosen, 5(4), pp. 2130. Available at: https:/ojs.unud.ac.id/index.php/jtip/article/downlo $\mathrm{ad} / 35543 / 21434$.

Oktaviani, E. P., Purwijantiningsih, L. M. E. and Pranat, F. S. (2014) 'Kualitas Dan Aktivitas Antioksidan Minuman Probiotik Dengan Variasi Ekstrak Buah Naga Merah (Hyloreceus Polyrhizus)', Jurnal Teknobiologi, pp. 1-15.

Puspitasari, T. (2012) Pengaruh Perbedaan Tipe Basis dan Konsentrasi Fraksi Etil Asetat Daun Binahong (Anredera cordifolia (Ten.) Steenis) Terhadap Sifat Fisik dan Kestabilan Sediaan Salep. Universitas Sebelas Maret.

Radji, M. (2011) Buku Ajar Mikrobiologi Panduan Mahasiswa Farmasi dan Kedokteran. Jakarta: Buku Kedokteran EGC.

Sandi, D. A. D. and Musfirah, Y. (2018) 'Pengaruh Basis Salep Hidrokarbon dan Basis Salep Serap Terhadap Formulasi Salep Sarang Burung Walet Putih (Aerodramus fuciphagus), Jurnal Ilmiah Manuntung, 4(2), p. 149. doi: 10.51352/jim.v4i2.194.

Sari, N. M. ., Hudha, A. . and Prihanta, W. (2016) 'Uji Kadar Betasianin Pada Buah Bit (Beta vulgaris L.) Dengan Pelarut Etanol Dan Pengembangannya Sebagai Sumber Belajar Biologi', Jurnal Pendidikan Biologi Indonesia, 2(1), pp. 72-77.

Ulaen, S., Banne, Y. and Suatan, R. (2012) 'Pembuatan Salep Anti Jerawat dari Ekstrak Rimpang Temulawak (Curcuma xanthorrhiza Roxb.)', Jurnal Ilmiah Farmasi Poltekkes Manado, 3(2), p. 96587.

Voigt, R. (1984) Buku Pelajaran Teknologi Farmasi. Yogyakarta: Universitas Gadjah Mada.
Farmasi. Yogyakarta: Gadjah Mada University Press.

Widyantoro, O. B. and Sugihartini, N. (2015) 'Uji Sifat Fisik Dan Aktivitas Ekstrak Daun Petai Cina ( Leucaena glauca, Benth ) Dalam Berbagai Tipe Evaluation Of Physicial Properties And Activity Test Of Extract Of Leucaena glauca, Benth Leaves In Variation Type Of Base Ointment As Wound', 12, pp. 48-60.

Voigt, R. (1995) Buku Pelajaran Teknologi 